\title{
Zastosowanie bezzałogowego statku latającego (UAV) w monitoringu powierzchniowym ruchów masowych na przykładzie osuwiska w Kasince Małej (Beskid Wyspowy, Zewnętrzne Karpaty Zachodnie)
}

\author{
Krzysztof Karwacki ${ }^{1}$
}

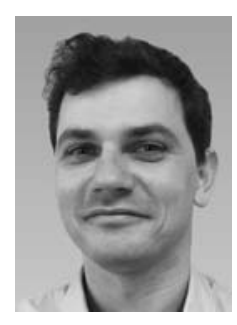

The application an unnamed aerial vehicle (UAV) in landslides surface monitoring - case study of the Kasinka Mała landslide (Beskid Wyspowy Mts., Outer Carpathians Mts.). Prz. Geol., 67: 339-350; doi: $10.7306 / 2019.28$

A b s t r a c t. Landslide monitoring is applied in case of a hazard for existing infrastructure located on hazardous landslide. It is the exact case of the Kasinka Mata landslide in the Outher Carpathians which causes a danger for the surrounding infrastructure. In order to measure the terrain deformations caused by landslide movements, the unnamed aerial vehicle equipped with a non-metric camera has been used. As a result of processing of aerial photos, orthophotomaps as well as digital elevation models have been produced. It enabled providing information about vertical and horizontal displacements caused by the landslide. The results of analysis shows that the mass movements occur at a different pace, but also that there are stable areas in the landslide. The application of UAV photogrammetry for landslide monitoring allows getting the information about the displacements in the unvegetated areas.

Keywords: landslide monitoring, image matching, LIDAR, photogrammetry, UAV

Jednym z głównych zadań po wykonaniu identyfikacji i wyznaczeniu zasięgu przestrzennego osuwisk jest określenie ich aktywności. Generalnie ocena ta nie sprawia większego problemu, gdy ruch osuwiska jest gwałtowny i tworzą się nowe skarpy, powstają szczeliny, zachodzą duże deformacje powierzchni terenu, czy osuwające się masy skalne powodują szkody w infrastrukturze. Bardzo często jednak dochodzi do sytuacji, gdy osuwisko, mimo że jest aktywne, ruch mas koluwialnych nie jest możliwy do wykrycia nieuzbrojonym okiem. W takich przypadkach zalecany jest monitoring instrumentalny prowadzony na powierzchni terenu oraz monitoring wgłębny (Bednarczyk, 2015, Wójcik i in., 2017). Pomiary wgłębne mają na celu wykrycie ruchu wewnątrz koluwium, gdzie w przypadku jego zaistnienia następuje odkształcenie kolumny inklinometrycznej na głębokościach, na których występują aktywne powierzchnie poślizgu (Zabuski, 2013; Nescieruk, 2015). Z kolei pomiary osuwiska na powierzchni są często prowadzone na podstawie stabilizowanych punktów, których współrzędne są mierzone cyklicznie, zazwyczaj metodami GNSS (Global Navigation Satellite System) lub metodami klasycznej geodezji. Dużą popularnością cieszą się również zdalne metody pomiarowe, do których należą fotogrametria i teledetekcja. Bardzo dobre wyniki są osiagane w wyniku skanowania laserowego LiDAR (Light Distance And Ranging) zarówno $\mathrm{z}$ pokładu lotniczego ALS (Airborne Laser Scanning) (Borkowski i in., 2011; Graniczny i in., 2012; Wojciechowski i in., 2012), jak i naziemnego TLS (Terrestrial Laser Scanning) (Kramarska i in., 2011), a ostatnio również z pułapu dronów ULS (UAVLaser Scanning) (Petrie, 2013; Jóźków i in., 2017; Salach i in., 2018), którego wynikiem jest wysokorozdzielcza chmura punktów odzwierciedlająca quasi ciagłą powierzchnie terenu. Rejestrację zmian zachodzących na powierzchni osuwisk wykonuje się również z pułapu satelitarnego, wykorzystując satelitarną interferometrię radarową (Wojciechow- ski i in., 2008; Perski i in., 2011). W wyniku przetwarzania scen satelitarnych można uzyskać przemieszczenia wysokościowe rzędu pojedynczych milimetrów, pod warunkiem występowania na obszarze osuwiska stałych elementów infrastruktury, takich jak drogi czy budynki. Coraz większe uznanie zyskuje lotnicza fotogrametria cyfrowa, która do niedawna, ze względu na ograniczoną dostępność materiału zdjęciowego, pozyskiwanego przy okazji większych projektów fotogrametrycznych typu PHARE (Poland and Hungary Assistance to the Reconstruction of the Economy) (Kurczyński, 1997) czy LPIS (Land Parcel Identification System) (Preuss, Kurczyński, 2002), była wykorzystywana częściej do odtwarzania historii osuwiska, niż do aktualnych obserwacji pojedynczych osuwisk i ich przemieszczeń (Tyszkowski, 2008; Kamiński, 2011; Karwacki, 2016). Dobre rezultaty można również uzyskać, stosując fotogrametrię bliskiego zasięgu. Jednak metoda ta ma uzasadnienie przede wszystkim przy niewielkich osuwiskach (Przyłucka, Klimkowska, 2016). Do większego zainteresowania się badaczy osuwisk metodami fotogrametrycznymi przyczynił się dynamiczny postęp technologiczny w konstruowaniu bezzałogowych statków latających (UAV Unmanned Aerial Vehicle) sterowanych radiem i zdolnych wykonywać loty autonomiczne. Nie bez znaczenia było równoczesne tworzenie i udoskonalanie algorytmów z zakresu automatycznego dopasowania obrazów (image matching), umożliwiających pozyskiwanie informacji o pokryciu terenu w postaci chmury punktów ze zdjęć optycznych (Niethammer i in., 2012). Dostępne na rynku oprogramowania fotogrametryczne umożliwiają przetwarzanie danych z obrazów optycznych wykonanych kamerami niemetrycznymi i budowanie na ich podstawie ortofotomap oraz numerycznych modeli pokrycia terenu (NMPT), a w sprzyjających warunkach - numerycznych modeli terenu (NMT). Dalsze przetwarzanie uzyskanych w ten sposób danych pozwala na monitorowanie aktywności osuwisk na podstawie

\footnotetext{
${ }^{1}$ Państwowy Instytut Geologiczny - Państwowy Instytut Badawczy, Centrum Geozagrożeń, ul. Rakowiecka 4, 00-975 Warszawa; krzysztof.karwacki@pgi.gov.pl
} 
wektorów przemieszczeń, zmian wysokościowych terenu czy objętości przemieszczonych mas skalnych (Niethammer i in., 2012; Lucieer i in., 2014; Graniczny i in., 2015; Neugirg i in., 2016; Karwacki, 2018; Kowalski i in., 2018; Rossi i in., 2018).

Eksperyment opisany poniżej przeprowadzono w celu wykazania możliwości zastosowania fotogrametrii lotniczej niskiego pułapu z wykorzystaniem UAV w detekcji zmian na powierzchni terenu wywołanych aktywnością osuwiska z uwzględnieniem pokrywy roślinnej.

\section{OBSZAR BADAŃ}

Próbne naloty przeprowadzono nad aktywnym osuwiskiem w Kasince Małej (gmina Mszana Dolna). Zostało ono zostało zarejestrowane na Mapie osuwisk i terenów zagrożonych $w$ skali 1:10 $000 \mathrm{w} 2009$ r. (Jurewicz i in., 2009). Do zsuwu mas skalnych doszło w 2010 r. na powierzchni ok. 1,5 ha, przy całkowitej powierzchni osuwiska wynoszącej ok. 9,5 ha (ryc. 1). W wyniku zachodzących ruchów grawitacyjnych powstały dwie nisze (skarpy) w

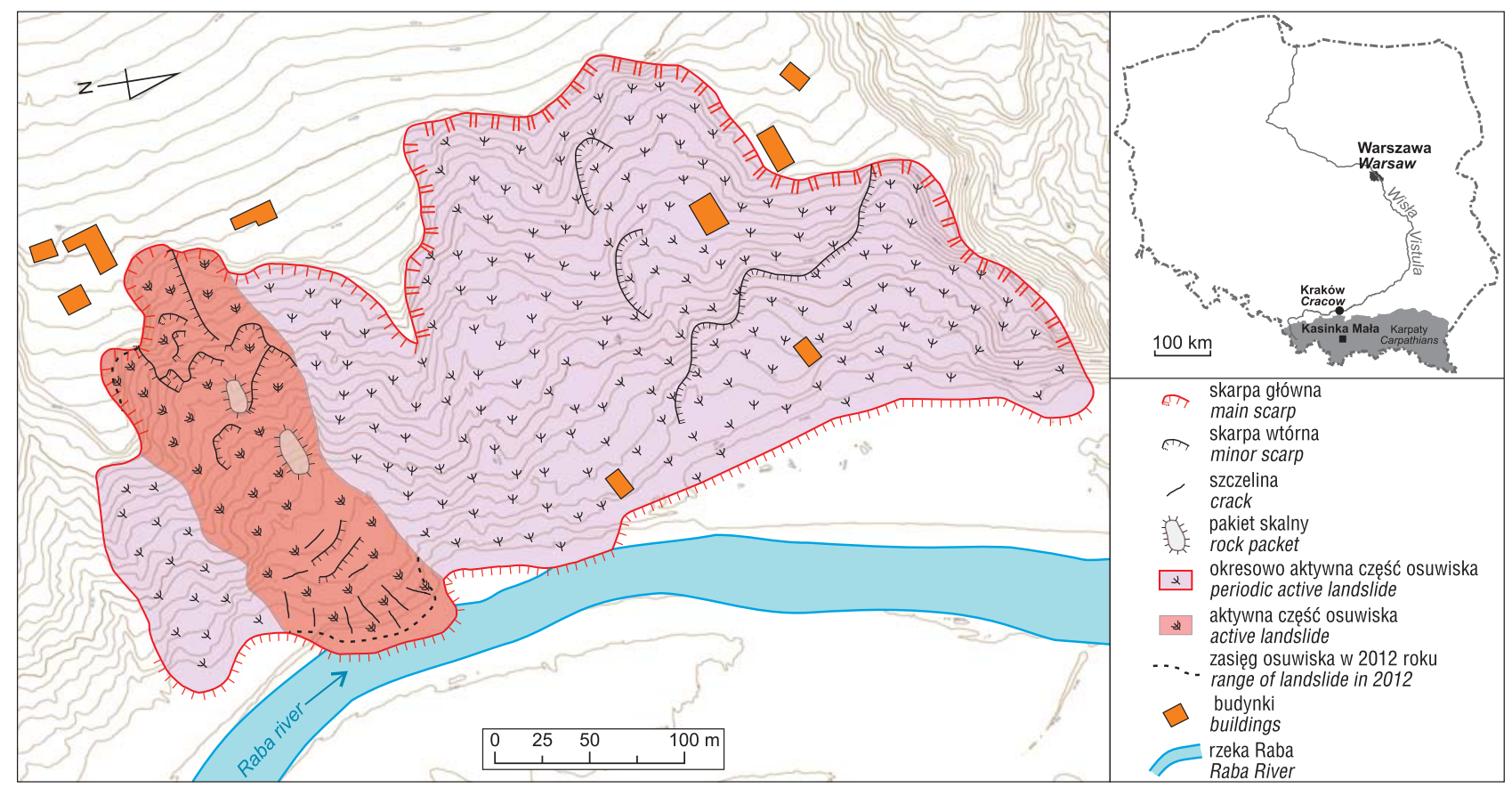

Ryc. 1. Szkic geomorfologiczny osuwiska w Kasince Małej

Fig. 1. Geomorphologic sketch-map of the Kasinka Mała landslide

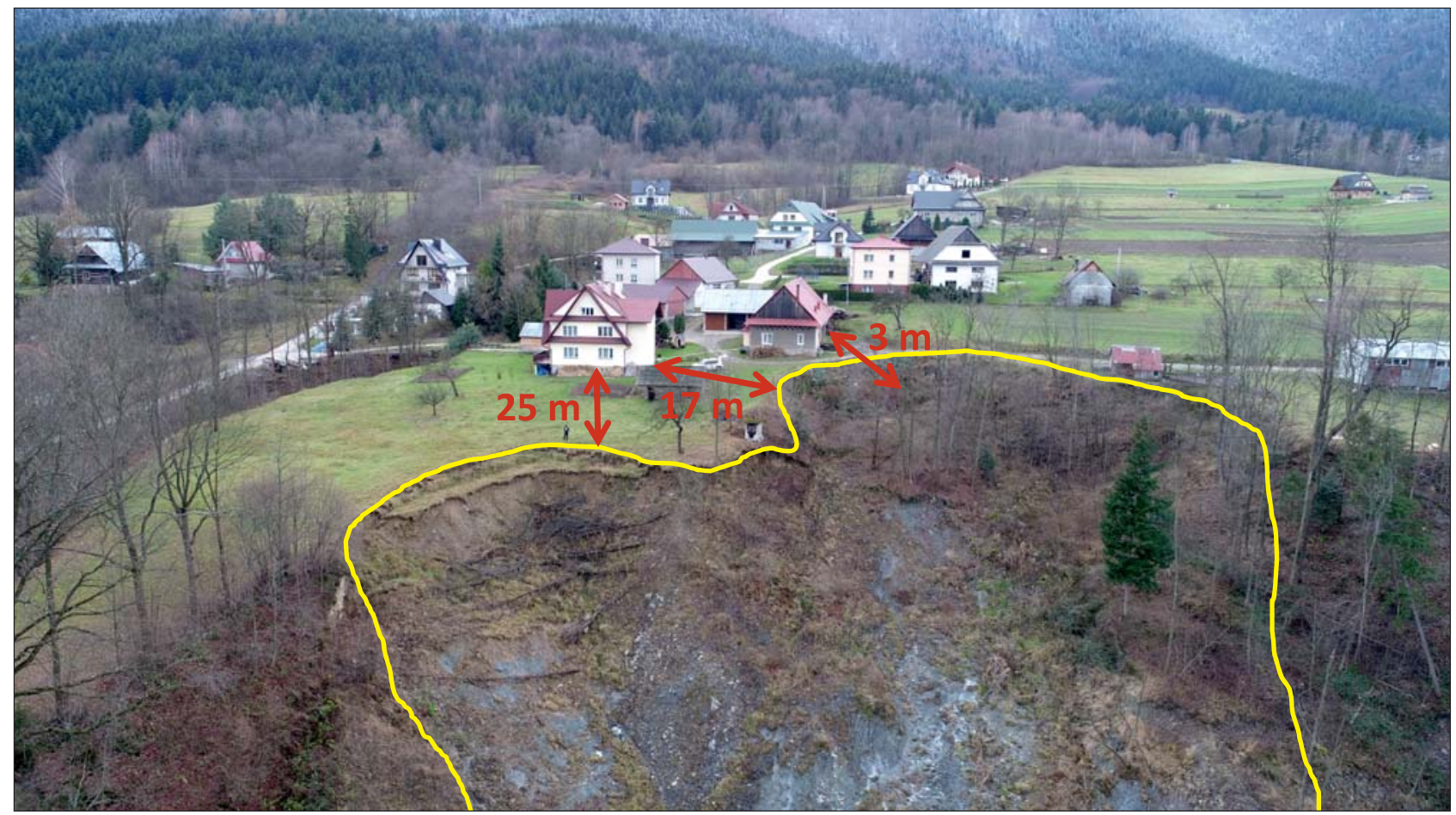

Ryc. 2. Skarpa główna i zagrożone budynki na osuwisku w Kasince Małej

Fig. 2. Main scarp and endangered buildings on the Kasinka Mała landslide 


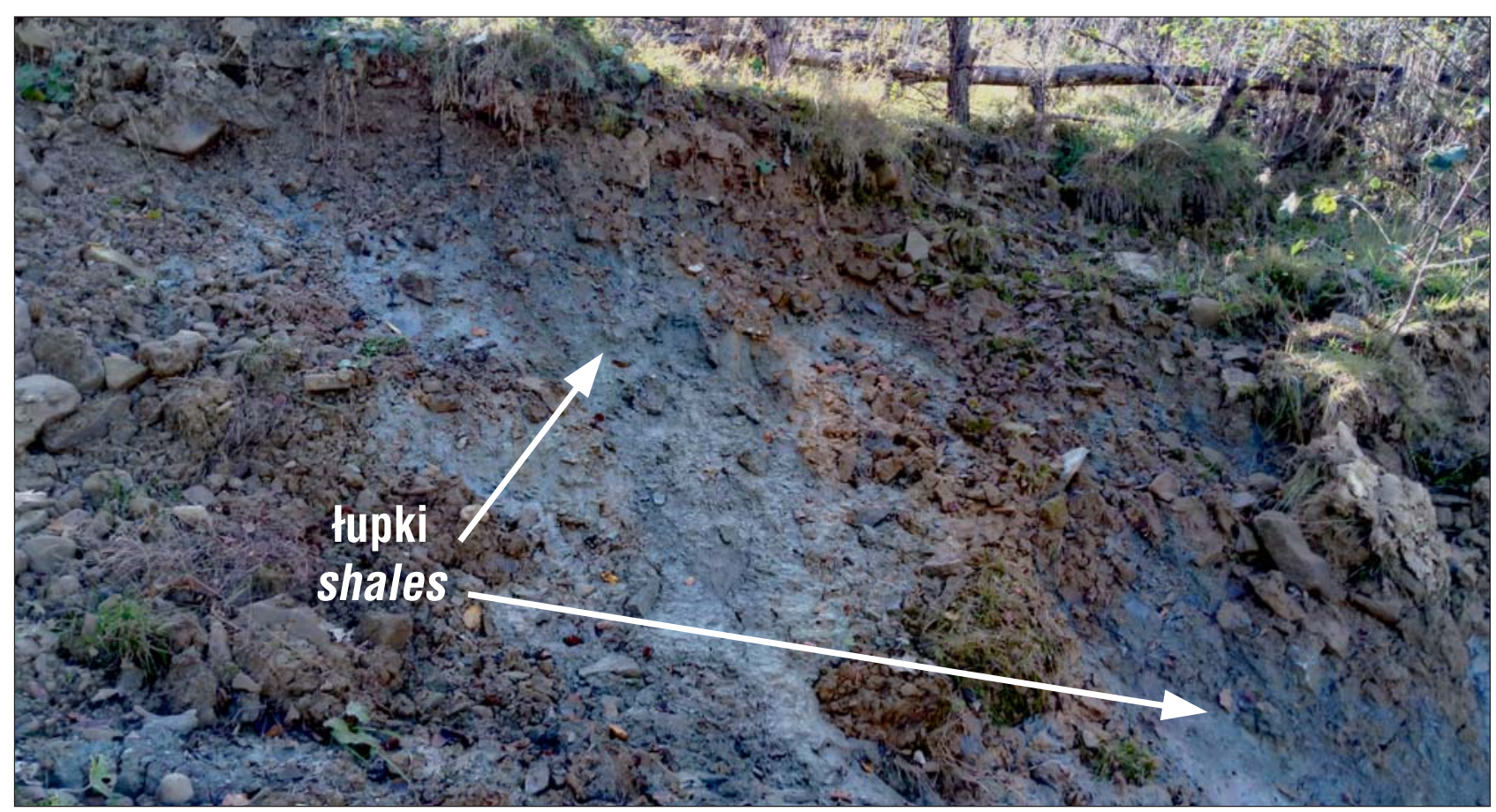

Ryc. 3. Osady odsłaniające się poniżej skarpy głównej

Fig. 3. Sediments located below the main scarp

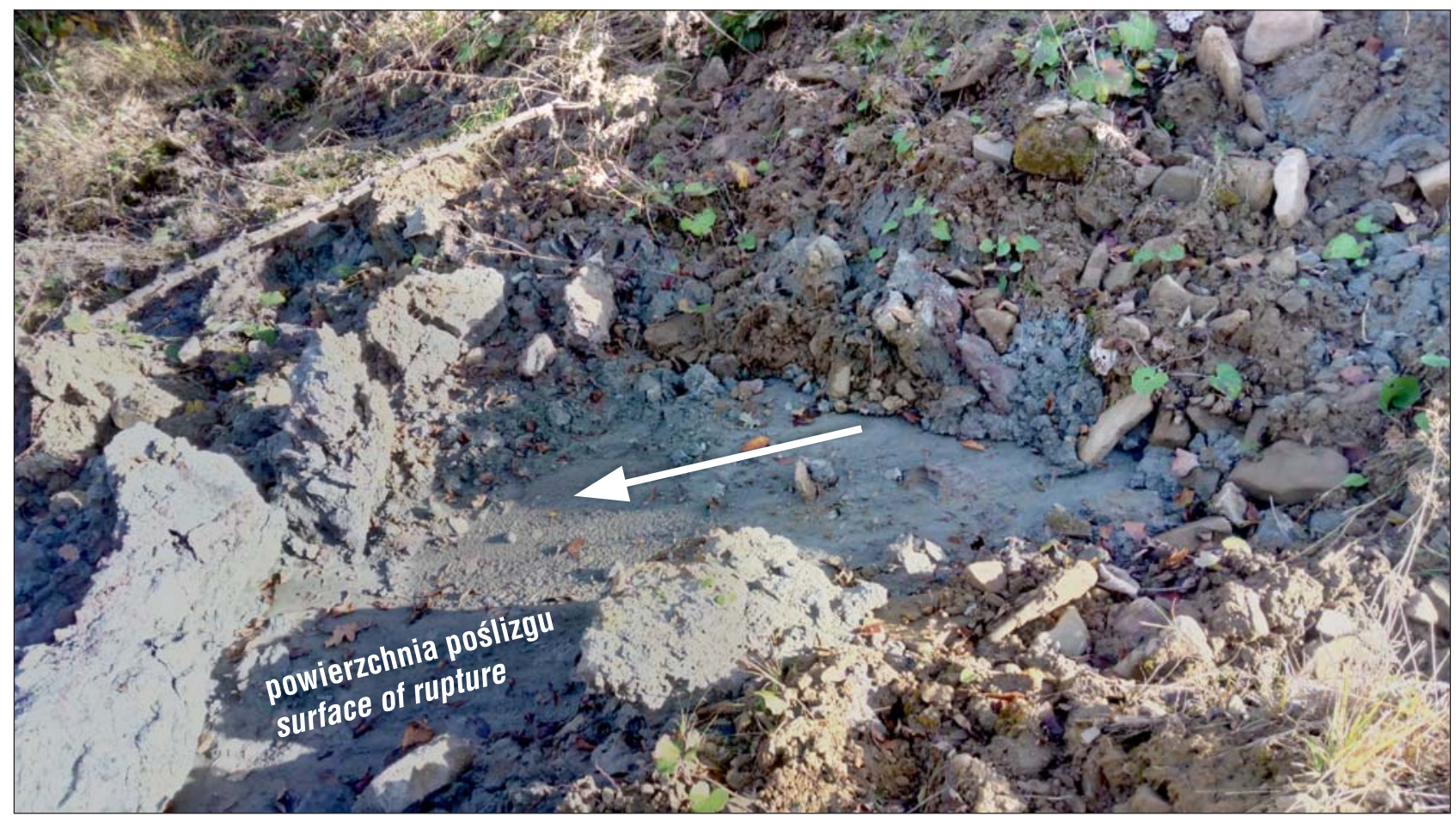

Ryc. 4. Powierzchnia poślizgu odsłaniająca poniżej skarpy głównej w niszy bocznej

Fig. 4. Slip surface exposed below the main scarp

górnej części osuwiska. W sąsiedztwie skarpy głównej znajduje się budynek gospodarczy, obecnie oddalony o zaledwie $3 \mathrm{~m}$ od jej krawędzi. Druga nisza (boczna) sukcesywnie zwiększa swój zasięg w górę stoku, a jej krawędź jest oddalona o ok. 25 m od budynku mieszkalnego (ryc. 2).

Geomorfologicznie osuwisko znajduje się w dolnej części stoku góry Szczebel o ekspozycji północno-wschodniej i jest podcinane przez rzekę Rabę.Część aktywna obejmuje obszar o długości ok. $250 \mathrm{~m}$ i szerokości ok. 90 m (ryc. 1). W momencie uaktywnienia się osuwiska ruch mas skalnych był dość szybki i miał charakter spływu gruzowo- -błotnego, o czym świadczy wał odsypowy znajdujący się od jego zachodniej strony (Wójcik, 2011). W dolnej części jęzor osuwiskowy nasuwa się na współczesne aluwia rzeki Raby, częściowo zasypując także koryto rzeki.

Według Starkla (1972) obszar ten należy do Tymbarskich Gór Wyspowych będących częścią Beskidu Wyspowego. Badane osuwisko rozwinęło się w obrębie warstw hieroglifowych płaszczowiny magurskiej (Burtan, 1974), reprezentowanych przez soliflukcyjne gliny z rumoszem skalnym (ryc. 3) barwy beżowej, oraz pojedyncze okruchy drobnoziarnistego piaskowca podścielone miękkimi, 
zawodnionymi iłami barwy stalowo-szarej oraz ciemnoszarymi iłołupkami marglistymi z okruchami i większymi głazami drobnoziarnistego piaskowca barwy popielatej (Nescieruk i in., 2015) (ryc. 4).

\section{METODYKA}

Nad osuwiskiem zrealizowano 3 naloty (27.11.2017, 24.03.2018 oraz 24.04.2018 r.). Do pozyskania materiału zdjęciowego wykorzystano bezzałogowy statek latający DJI Phantom 4 Advance. Został on wyposażony w niemetryczną kamerę DJI FC6310 z obiektywem o ogniskowej $9 \mathrm{~mm}$ oraz matrycę wielkości 1 cala z możliwością rejestracji obrazu o rozdzielczości 20 megapikseli. Pierwszy nalot był zrealizowany w trybie manualnym. Dwie kolejne misje zaplanowano w aplikacji Ground Station PRO (DJI) i zrealizowano w trybie autonomicznym pod stała kontrola operatora UAV. Zdjęcia wykonano z pułapu od 52 do $81 \mathrm{~m}$ (AGL - Above Ground Level), uzyskując rozmiar piksela (GSD - Ground Sample Distance) na poziomie 1,7-2,1 cm (tab. 1). Zdjęcia osuwiska w dniu 24.03.2018 r. pozyskano w trakcie dwóch misji lotniczych, uwzględniając nachylenie powierzchni osuwiska.

Kalibrację kamery wykonano za pomocą oprogramowania Agisoft Photoscan na podstawie pozyskanych zdjęć. Aerotriangulację przeprowadzono przy użyciu sygnalizowanej (s), a w przypadku pierwszego nalotu niesygnalizowanej (ns) osnowy fotogrametrycznej (GCP - Ground Control Points). Jako punkty osnowy sygnalizowanej posłużyły tarcze o wymiarach $50 \times 50 \mathrm{~cm}$. Ich środki zostały pomierzone metodą GPS-RTK (Global Positioning System - Real Time Kinematic) odbiornikiem HiTarget V30, z wykorzystaniem poprawek w czasie rzeczywistym serwisu ASG EUPOS (Aktywna Sieć Geodezyjna - European Position Determination System), uzyskując dokładność sytuacyjną $2 \mathrm{~cm}$ i wysokościową $5 \mathrm{~cm}$. Elementy osnowy niesygnalizowanej (studzienki, płytki chodnikowe czy większe głazy na terenie osuwiska) dla pierwszego nalotu zostały zmierzone tą samą metoda, $z$ jednodniowym opóźnieniem w stosunku do momentu wykonania zdjęć.

Aerotriangulację przeprowadzono metodą niezależnych wiązek, która polega na wyznaczeniu zależności pomiędzy współrzędnymi obrazowymi fotopunktów oraz punktów wiążących a współrzędnymi terenowymi fotopunktów. Błędy wyrównania na fotopunktach (control points) oraz błędy na punktach kontrolnych (check points) przedstawiono w tabeli 2.

W wyniku automatycznego dopasowania obrazów uzyskano gęstą chmurę punktów (tab. 3). Wstępną filtrację punktów przeprowadzono za pomocą oprogramowania Agisoft Photoscan, wykorzystując algorytm pozwalający odseparować punkty klasy ,grunt” od pozostałych punktów. Następnie z wykorzystaniem oprogramowania LP360 dokonano kontroli i przeprowadzono klasyfikację manualną, usuwając punkty, które nie odzwierciedlały powierzchni terenu. Numeryczny model terenu w nieregularnej siatce trójkątów (TIN - Triangulated Irregular Network) zbudowano na podstawie uzyskanych $\mathrm{w}$ powyższym procesie

Tab. 1. Parametry nalotów fotogrametrycznych

Table 1. Parameters of photogrammetric fly missions

\begin{tabular}{|l|c|c|c|c|c|c|c|}
\hline $\begin{array}{c}\text { Lp. } \\
\text { No. }\end{array}$ & $\begin{array}{c}\text { Data nalotu } \\
\text { Fly mission date }\end{array}$ & $\begin{array}{c}\text { GSD } \\
\text { Ground Sample } \\
\text { Distance } \\
{[\mathbf{c m}]}\end{array}$ & $\begin{array}{c}\text { AGL } \\
\text { Above } \\
\text { Ground Level } \\
{[\mathbf{m}]}\end{array}$ & $\begin{array}{c}\text { GCP } \\
\text { Ground Control } \\
\text { Points }\end{array}$ & $\begin{array}{c}\text { Pokrycie zdjećc } \\
\text { Image overlap } \\
{[\%]}\end{array}$ & $\begin{array}{c}\text { Prędkość nalotu } \\
\text { Speed of fly mission } \\
{[\mathbf{m} / \mathbf{s}]}\end{array}$ & $\begin{array}{c}\text { Liczba zdjęć } \\
\text { No. of photos }\end{array}$ \\
\hline 1 & 28.11 .2017 & 1,7 & 69 & $17(\mathrm{~ns})$ & $<80 /<60$ & - & 201 \\
\hline 2 & 24.03 .2018 & 2,1 & 81 & $18(\mathrm{~s})$ & $\begin{array}{c}93 / 87 \\
95 / 87\end{array}$ & 3,5 & 432 \\
\hline 3 & 24.04 .2018 & 1,9 & 77 & $13(\mathrm{~s})$ & $80 / 77$ & 3,5 & 301 \\
\hline
\end{tabular}

Tab. 2. Wyniki aerotriangulacji dla 3 nalotów

Table 2. Results of aerotriangulation for 3 flight missions

\begin{tabular}{|l|c|c|c|c|c|c|}
\hline $\begin{array}{c}\text { Data nalotu } \\
\text { Fly mission date }\end{array}$ & $\begin{array}{c}\text { Fotopunkty } \\
\text { Ground control } \\
\text { points }\end{array}$ & $\begin{array}{c}\text { Punkty kontrolne } \\
\text { Check points }\end{array}$ & $\begin{array}{c}\text { RMSE X } \\
{[\mathbf{c m}]}\end{array}$ & $\begin{array}{c}\text { RMSE Y } \\
{[\mathbf{c m}]}\end{array}$ & $\begin{array}{c}\text { RMSE Z } \\
{[\mathbf{c m}]}\end{array}$ & $\begin{array}{c}\text { Total error } \\
{[\mathbf{c m}]}\end{array}$ \\
\hline \multirow{2}{*}{28.11 .2017} & 13 & - & 3,3 & 1,9 & 1,1 & 4,0 \\
\hline \multirow{2}{*}{24.03 .2018} & - & 4 & 2,1 & 1,8 & 2,8 & 4,0 \\
\hline \multirow{2}{*}{24.04 .2018} & 14 & - & 1,9 & 1,7 & 2,5 & 3,6 \\
\cline { 2 - 7 } & - & 4 & 1,8 & 2,2 & 1,2 & 3,1 \\
\hline
\end{tabular}

Tab. 3. Porównanie parametrów chmur punktów uzyskanych w procesie automatycznego dopasowania obrazów Table 3. Comparison of point cloud parameters obtained from the image matching process

\begin{tabular}{|l|c|c|c|c|}
\hline $\begin{array}{c}\text { Data nalotu } \\
\text { Fly mission date }\end{array}$ & $\begin{array}{c}\text { Liczba wszystkich } \\
\text { punktów } \\
\text { Total numer of points }\end{array}$ & $\begin{array}{c}\text { Liczba punktów w klasie, grunt” } \\
\text { No. of points in the class ground }\end{array}$ & $\begin{array}{c}\text { Srednia gesstość punktów } \\
\text { klasy grunt } \\
\text { Mean density of points } \\
\text { in ground class } \\
\left.\text { [pkt/m } \mathbf{m}^{2}\right]\end{array}$ & $\begin{array}{c}\text { RMS reprojection error } \\
\text { (pix) }\end{array}$ \\
\hline 28.11 .2017 & 9248917 & 8236880 & 234 & 1,6 \\
\hline 24.03 .2018 & 7298773 & 6703509 & 190 & 1,4 \\
\hline 24.04 .2018 & 10114726 & 5076950 & 144 & 1,6 \\
\hline
\end{tabular}


punktów klasy „grunt”. Dla każdego nalotu wygenerowano ortoobrazy w rzucie ortogonalnym, połączone do ortomozaiki, na których pomierzono współrzędne punktów charakterystycznych.

\section{WYNIKI}

Analizę przemieszczeń w obrębie osuwiska wykonano na podstawie ortomozaik i numerycznych danych wysokościowych uzyskanych za pomocą UAV. Jako punkt odniesienia do analiz przyjęto numeryczny model terenu z $2012 \mathrm{r}$. o rozdzielczości $1 \mathrm{~m}$, wygenerowany na potrzeby projektu ISOK- Informatyczny System Osłony Kraju (Kurczyński i in., 2014).

\section{Przemieszczenia poziome}

W pierwszej kolejności wyinterpretowano zasięg osuwiska na modelu z 2012 r. oraz na ortomozaice z nalotów UAV o GSD wielkości 2-3 cm. Do znaczącej zmiany zasię- gu doszło w okresie między 2012 i 2017, kiedy to osuwisko w górnej części powiększyło swój zasięg o 5 m, a w części dolnej czoło osuwiskowe przesunęło się o $7 \mathrm{~m}$, zasypując częściowo koryto rzeki Raby (ryc. 1). Zmiany zasięgu osuwiska między nalotami UAV były nieznaczne. W górnej części uwidoczniły się przesunięciem niewielkiego odcinka krawędzi skarpy głównej, zwiększając powierzchnię osuwiska o zaledwie $10 \mathrm{~m}^{2}$. W dolnej - w tym samym okresie zaobserwowano przesunięcie czoła w kierunku rzeki na odległość ok. $65 \mathrm{~cm}$. Na powierzchni osuwiska występuje duża liczba obiektów (większe głazy, konary drzew itp.) jednoznacznie identyfikowalnych na ortomozaikach z UAV. $\mathrm{Na}$ podstawie pomiaru ich współrzędnych wyznaczono poziome wektory przemieszczeń, które przedstawiają zróżnicowane tempo ruchu osuwiska w poszczególnych jego częściach.

Dla okresu od 28.11.2017 do 24.03.2018 r. wyznaczono 190 wektorów (ryc. 5). Największe poziome przesunięcia zarejestrowano w części centralnej (ponad $5 \mathrm{~m}$ ), na styku dwóch głównych kanałów transportujących masy skalne

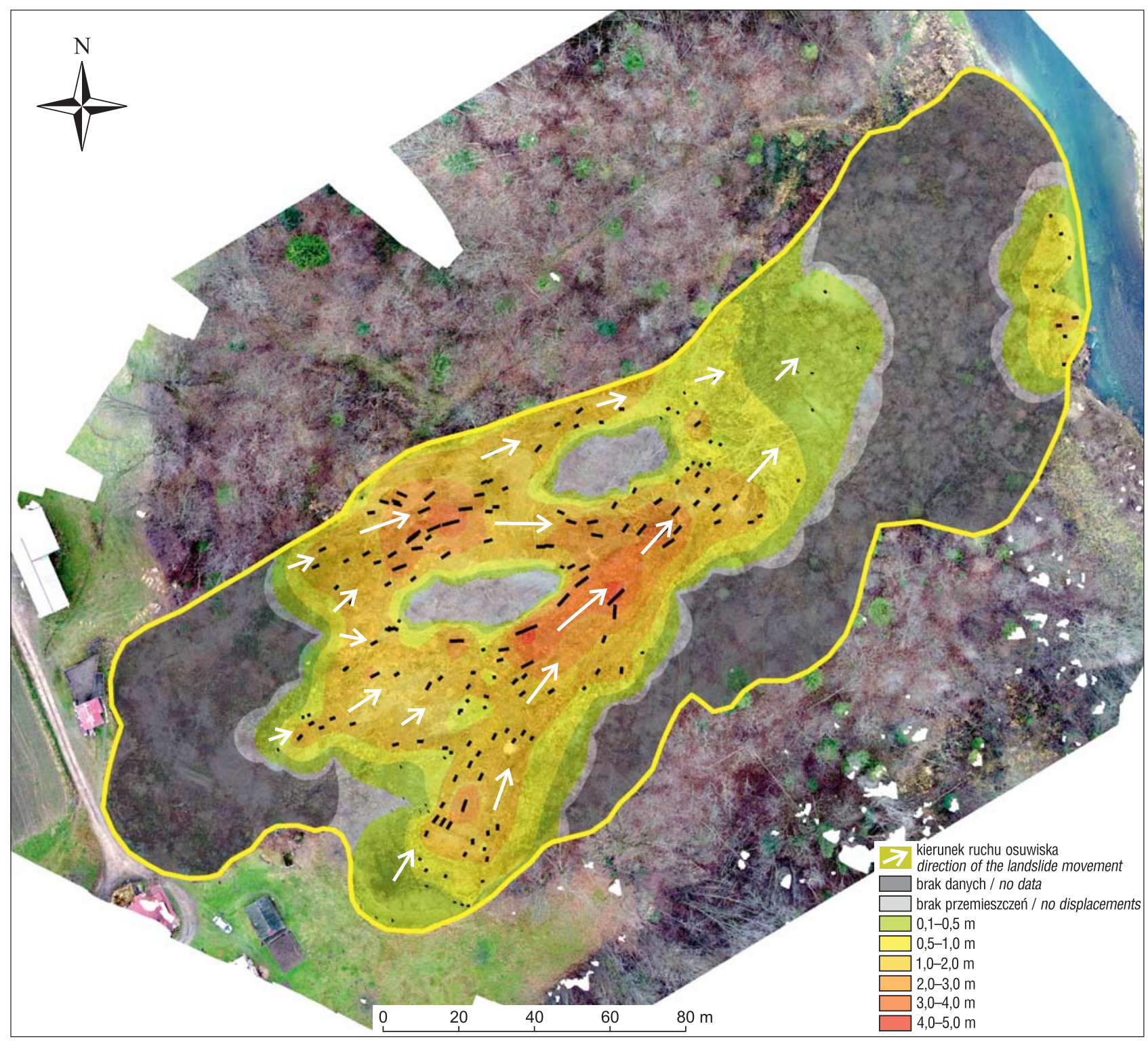

Ryc. 5. Mapa przemieszczeń poziomych między pierwszym i drugim nalotem UAV wygenerowana metodą naturalnego sąsiedztwa z poziomych wektorów przemieszczeń

Fig. 5. Horizontal displacement map done between the $1^{\text {st }}$ and the $2^{\text {nd }} U A V$ fly mission generated with the natural neighbor method from the horizontal displacement vectors 
w obrębie jęzora. Najmniejsze wartości wektorów występują w górnej części, gdzie ruch mas skalnych się rozpoczyna oraz w części dolnej, na której nie ma jeszcze zwartej roślinności. Obszar czoła i skarpy głównej osuwiska jest pokryty zwartą roślinnością, co uniemożliwia analizę. Przemieszczenia obserwuje się tylko na niewielkim obszarze położonym w centralnej części czoła, stwierdzono tam przesunięcia rzędu $1 \mathrm{~m}$. Zmian sytuacyjnego położenia obiektów nie wykazują dwa obszary w centralnej części osuwiska (ryc. 5).

Ruch mas skalnych jest rejestrowany również między 2 i 3 nalotem. Różnice we współrzędnych charakterystycznych obiektów w okresie jednego miesiąca były na tyle duże, że pozwoliły wygenerować ponad 160 wektorów (ryc. 6). Mimo tak niewielkiego interwału czasowego można zauważyć istotne zmiany na powierzchni. Największe wartości wektorów zaobserwowano w północnej (2 m) oraz centralnej części $(1,4 \mathrm{~m})$, natomiast niewielkie poniżej skarpy głównej, w centrum niszy bocznej, a także w obrębie niewielkiego fragmentu czoła. Brak przemiesz- czeń poziomych dobrze zaznacza się w dwóch obszarach znajdujących się w centrum osuwiska.

\section{Przemieszczenia wysokościowe}

Analizę zmian wysokościowych wykonano na podstawie modeli różnicowych wygenerowanych z NMT wykonanych ze zdjęć z UAV oraz na podstawie modelu w siatce $1 \mathrm{~m}$ z projektu ISOK. Dla zwizualizowania zmian wysokościowych przyjęto wartości większe od $10 \mathrm{~cm}$.

Pierwszy model różnicowy (ryc. 7) pokazuje przemieszczenia w profilu pionowym między rokiem 2012 i 2017. Wyraźnie zaznaczają się strefy oderwania (alimentacji) z ubytkiem materiału i strefy akumulacji mas skalnych. W części północno-zachodniej skarpy głównej znajduje się strefa $\mathrm{z}$ naprzemianległymi obszarami z ubytkiem $(-2,7 \mathrm{~m})$ i akumulacją materiału skalnego $(1,5 \mathrm{~m})$ Widoczny jest też przyrost na krawędzi niszy, będący działaniem antropogenicznym polegającym na zasypywaniu osuwiska. W strefie skarpy głównej w części północno-wschodniej teren

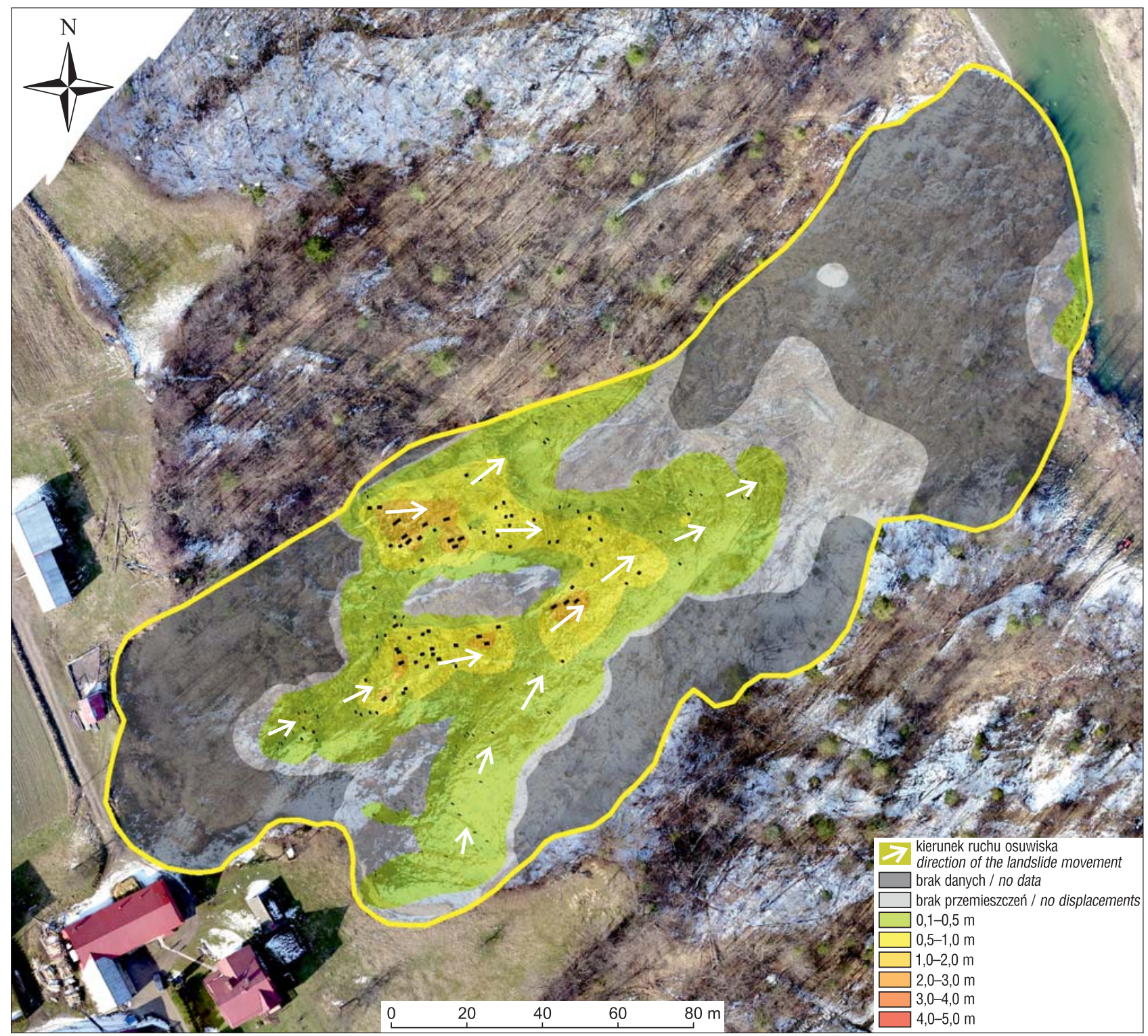

Ryc. 6. Mapa przemieszczeń poziomych między drugim i trzecim nalotem UAV wygenerowana metodą naturalnego sąsiedztwa z poziomych wektorów przemieszczeń

Fig. 6. Horizontal displacement map done between the $2^{\text {nd }}$ and the $3^{\text {nd }} U A V$ fly mission generated with the natural neighbor method from the horizontal displacement vectors 


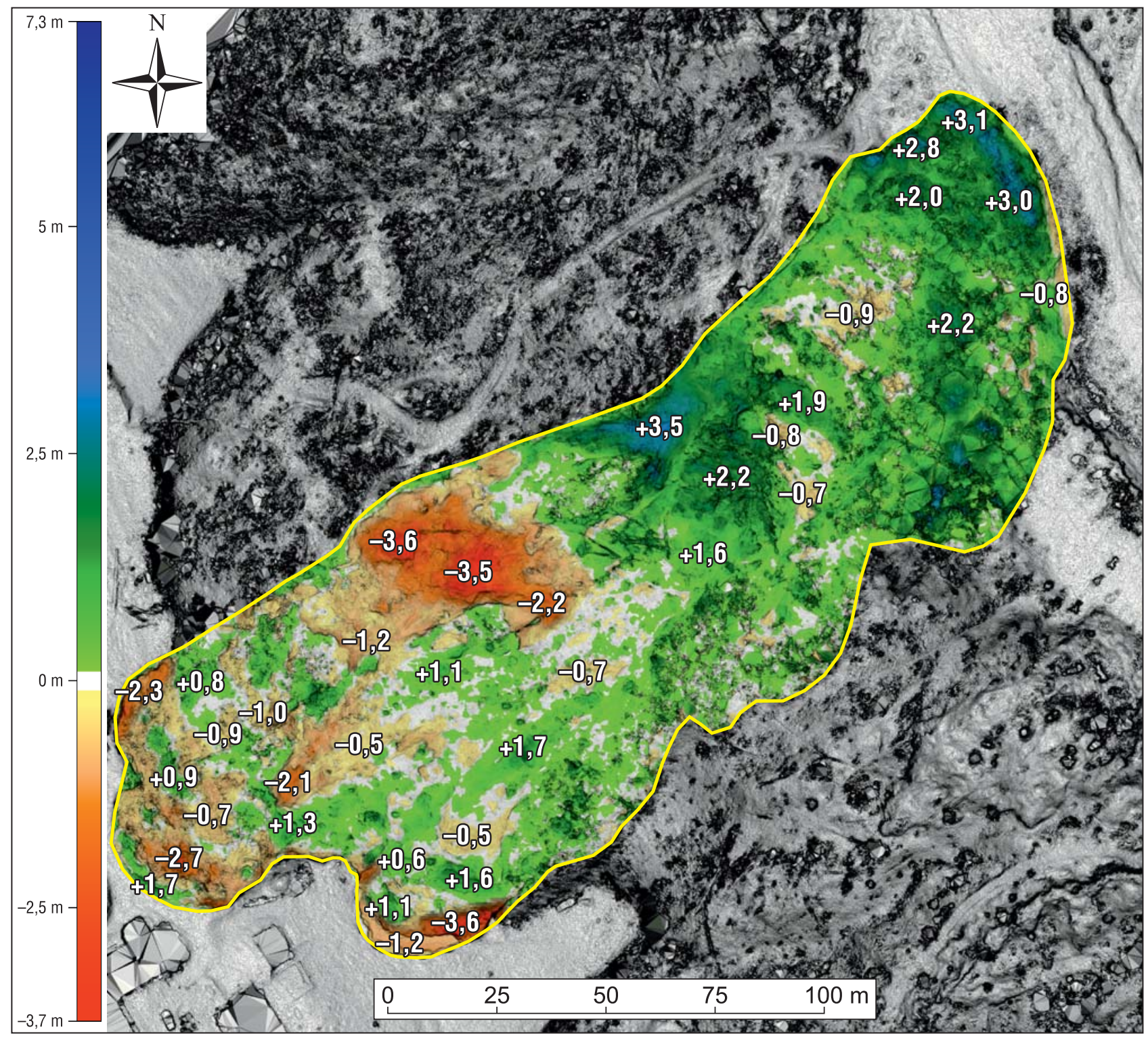

Ryc. 7. Wysokościowy model różnicowy wygenerowany na podstawie modelu z 2012 r. (ISOK) i listopada 2018 r. (UAV)

Fig. 7. Difference height model generated on the basis of the models from 2012 (ISOK) and November 2018 (UAV)

obniżył się maksymalnie o 3,5 m, a osunięty materiał został zdeponowany poniżej, powodując podniesienie terenu o ponad 1,6 m. W części centralnej osuwiska doszło do dużych zmian wysokościowych, w wyniku których teren obniżył się o nawet 3,6 m. Poniżej tej strefy nastąpiła akumulacja materiału, powodując podniesienie terenu o 3,5 m. Dolna część osuwiska to wiele naprzemianległych stref z ubytkiem i przyrostem mas skalnych. W strefie czołowej osuwiska występują wyraźne przyrosty koluwium rzędu 3,0 m, korelujące się ze zmianą zasięgu osuwiska w opisywanym interwale czasowym. Niewielkie ubytki są obserwowane na krawędzi czoła.

Podobnie jak w przypadku przemieszczeń poziomych, w okresie między pierwszym i drugim nalotem UAV (tab. 1) doszło również do zmian wysokościowych (ryc. 8). Jest to szczególnie dobrze widoczne w górnej części osuwiska. Poniżej skarp osuwiska teren obniżył się o $0,4 \mathrm{~m}$ w części południowo-wschodniej oraz 1,2 m w części południowo-zachodniej (ryc. 8A). Do przemieszczeń doszło także w części centralnej osuwiska, gdzie pojawiły się niewielkie następujące po sobie strefy z ubytkiem i przyrostem mas skalnych. W niewielkich fragmentach, w strefie podcinania czoła przez wody rzeki Raby zaobsewowano strefy z ubytkiem i akumulacją świadczące o nieustanie zachodzących procesach grawitacyjnych w tej części jęzora.

Deformacje wysokościowe odnotowano również między drugim i trzecim nalotem (ryc. 9). Bardzo niewielkie przemieszczenia wystąpiły w strefie skarpy głównej (ryc. 9A). Do nieco większych zmian wysokościowych doszło w centralnej części osuwiska (ryc. 9B), gdzie teren obniżył się nawet o 1,3 m. W tym fragmencie osuwiska stwierdzono niewielkie obszary z akumulacja, poprzedzone strefami z ubytkiem materiału skalnego. W dolnej części jęzora nie ma możliwości analizy zmian wysokościowych z powodu błędów modelu terenu, które wynikają z pokrycia terenu roślinnością (ryc. 9C).

\section{DYSKUSJA}

Przeprowadzone badania służyły określeniu przydatności bezzałogowego statku latającego w monitorowaniu aktywności osuwiska. Do prześledzenia ruchu osuwiska wykorzystano dane wysokościowe (NMT) oraz ortomozaiki 


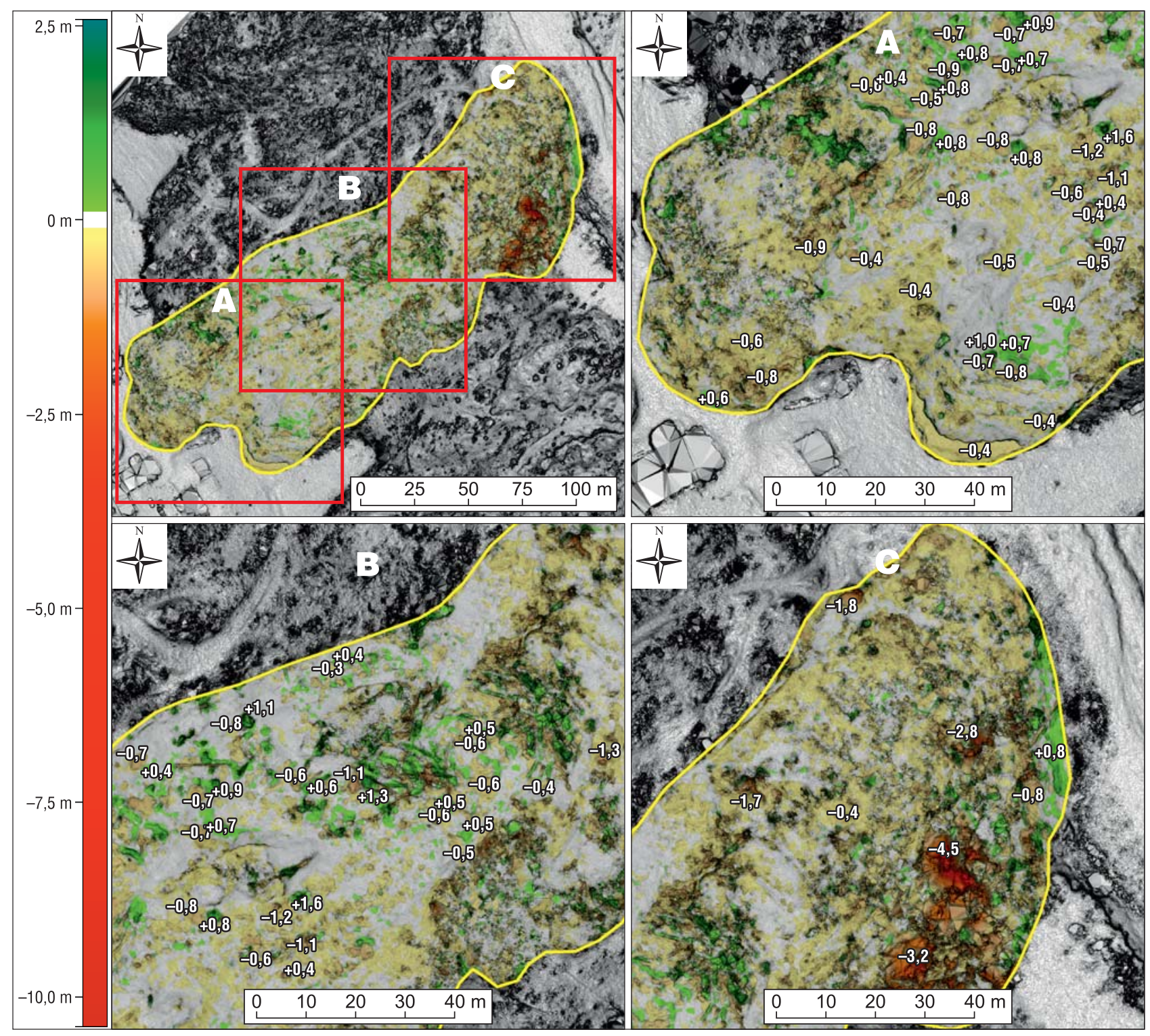

Ryc. 8. Wysokościowy model różnicowy wygenerowany na podstawie modeli z 28.11.2017 i $24.03 .2018 \mathrm{r}$.

Fig. 8. Difference height model generated on the basis of the models from 28.11.2017 (UAV) and 24.03.2018 (UAV)

wygenerowane ze zdjęć lotniczych z pokładu UAV. Analiza danych pokazała zróżnicowane natężenie przemieszczeń na obszarze osuwiska. Pomiary wykonane w oparciu o ortomozaikę pokazały 3 główne obszary alimentacyjne, w których rozpoczyna się ruch horyzontalny (ryc. 5, 6) oraz wyraźne kanały transportowe z rumoszem skalnym (ryc. 10, 11). Za wiarygodne przemieszczenia horyzontalne przyjęto różnice w położeniu obiektu większe niż $15 \mathrm{~cm}$. Największy ruch powierzchniowy jest obserwowany w części centralnej osuwiska, co jest spowodowane połączeniem dwóch kanałów transportowych (ryc. 10).

Z obserwacji osuwiska wynika, że przemieszczenia na osuwisku mają charakter powolny i ciągły. Średnie tempo zsuwu w strefie najszybciej przemieszczającej się wynosi ok. 5 cm/dzień (24.03.2018-28.11.2017 r.), co pozwala je zaliczyć do osuwisk o powolnym ruchu wg klasyfikacji Crudena i Varnesa (1996), ale dość szybkim ruchu, jak na osuwiska w polskiej części Karpat. Transportowany materiał skalny w części centralnej osuwiska omija dwa pakiety skalne, na których nie dochodzi do przemieszczeń. Około 30 metrów poniżej stabilnej strefy (pakietu) ruch horyzon- talny zanika. Dopiero w południowo-wschodniej części osuwiska przemieszczenie poziome jest zauważalne, co jest spowodowane erozją czoła osuwiska przez wody Raby.

Ruch osuwiska został również zarejestrowany na danych wysokościowych. Dane te pozyskano ze zdjęć wykonanych z pokładu UAV w procesie automatycznego dopasowania obrazów. Pomiary wysokościowe osuwiska można uznać za wiarygodne tylko w strefach pozbawionych roślinności.

Na jakość uzyskanej chmury punktów ogromny wpływ miało pokrycie terenu. Pierwszy nalot zrealizowano w okresie jesiennym, w którym drzewa były częściowo pozbawione ulistnienia. Drugi nalot przeprowadzono na przełomie zimy i wiosny, przy zalegającej niewielkiej pokrywie śnieżnej, kiedy rośliny były pozbawione liści. Trzeci nalot wykonano wiosną, w okresie w którym roślinność wytworzyła świeże liście.

Najlepszej jakości chmurę punktów wygenerowano z nalotu drugiego (24.03.2018 r.). Przewaga nad pozostałymi danymi wysokościowymi jest szczególnie dobrze widoczna w dolnej części jęzora osuwiskowego. Pozbawiona liści roślinność drzewiasta i krzewiasta nie stanowiła przeszkody dla algorytmu generującego punkty 


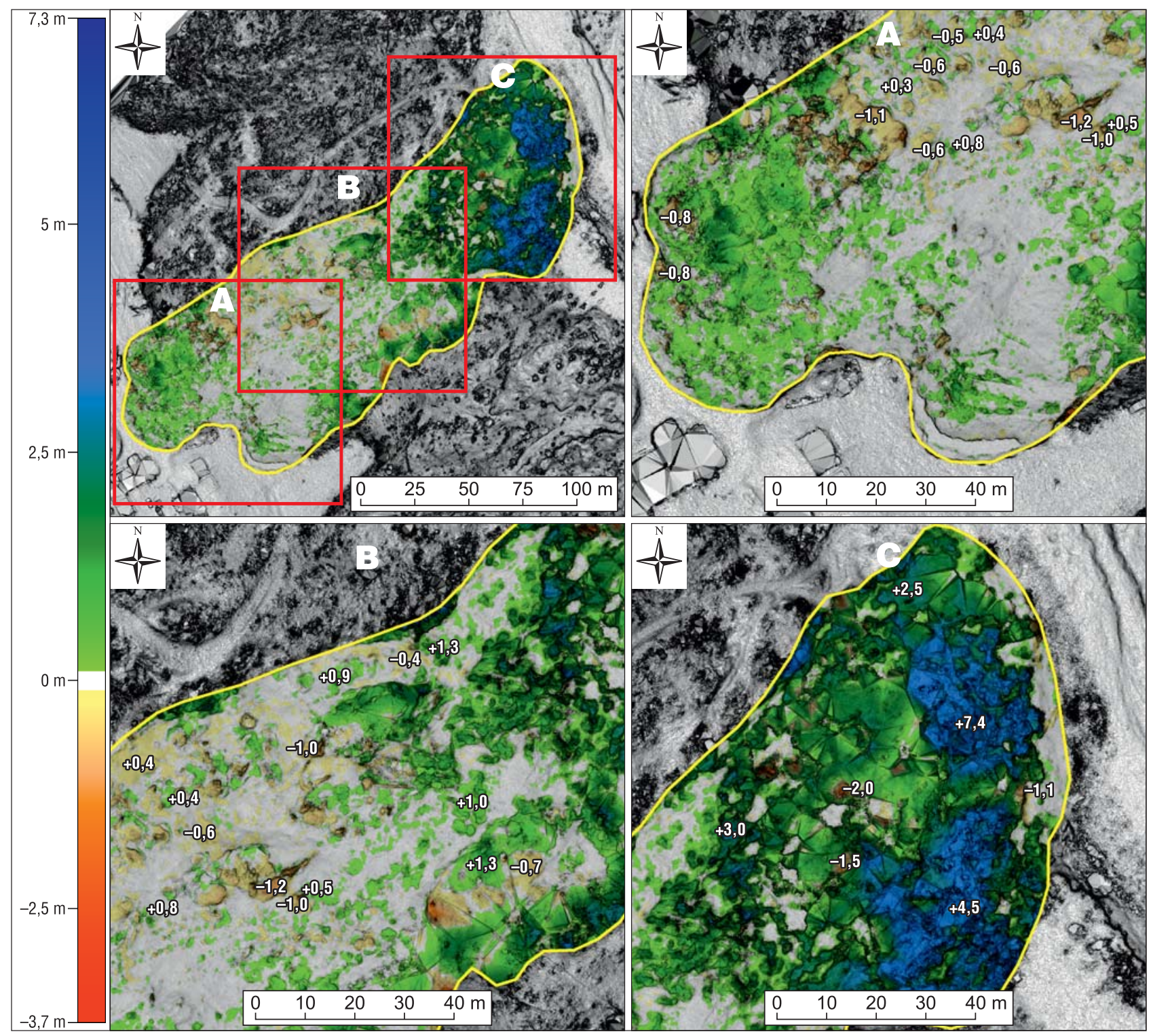

Ryc. 9. Wysokościowy model różnicowy wygenerowany na podstawie modeli z 24.03.2018 i 24.04 .2018 r.

Fig. 9. Difference height model generated on the basis of the models from 24.03.2018 (UAV) and 24.04.2018 (UAV)

wysokościowe klasy „grunt”. Pozwoliło to obliczyć dobrej jakości numeryczny model terenu, w niewielkim stopniu zniekształcony przez pokrywę roślinną. Chmura punktów z pierwszego nalotu dobrze odzwierciedla teren odkryty, natomiast na obszarze pokrytym roślinnością niewiele punktów reprezentuje powierzchnię terenu. Najwięcej szumu związanego z roślinnością znajduje się w chmurze punktów wygenerowanej ze zdjęć nalotu trzeciego. Na obszarze pokrytym roślinnością punkty odzwierciedlające powierzchnię terenu nie występują. Ponadto można zauważyć, że w stosunku do pozostałych nalotów pakiety osuniętego materiału skalnego są pokryte roślinnością. Mimo zastosowanej klasyfikacji automatycznej oraz kontroli i klasyfikacji manualnej nie wyeliminowano błędów modelu wynikających $\mathrm{z}$ istniejącej pokrywy roślinnej. Z uwagi na zniekształcenia opisane powyżej, analizę danych wysokościowych (NMT) przeprowadzono w odniesieniu do zobrazowań optycznych, co pozwoliło wyeliminować przypadkowe różnice.

W stosunku do zarejestrowanych przemieszczeń horyzontalnych przemieszczenia wertykalne są obserwowane na obszarze całej aktywnej strefy osuwiska pozbawionej roślinności (ryc. 7, 8, 9). Największe deformacje wystąpiły między rokiem 2012 i 2017 (ryc. 7), ale model ten obejmuje najdłuższy okres badania zmian. Można przyjąć, że jest to ogólny obraz prezentujący rozmieszczenie stref z ubytkiem i akumulacją materiału skalnego w strefie aktywnej. Kolejne modele różnicowe (ryc. 8, 9) utrzymują tą tendencję, szczególnie w przypadku stref, w których dochodzi do ubytku materiału skalnego. Ruch wertykalny jest kontynuowany w górnych partiach osuwiska w strefach poniżej skarpy głównej w okresie zimowym, między 28.11.2017 a 24.03.2018 r. (ryc. 8), oraz w centralnej części osuwiska w okresie wiosennym (ryc. 9). Większe strefy z akumulacją materiału są możliwe do zinterpretowania tylko w wypadku modelu pierwszego (ryc. 7), w którym doszło do przesunięcia czoła osuwiska, a tym samym przyrostu wysokościowego. Wzrost wysokości terenu pojawia się na nim również tuż za obniżeniem w centralnej części.

$\mathrm{Na}$ modelach różnicowych wygenerowanych z danych UAV trudno dostrzec większe strefy $\mathrm{z}$ akumulacją koluwium. Niewielkie strefy naprzemianległych ubytków i przyrostów materiału skalnego są widoczne w części centralnej osuwiska (ryc. 8B, 9B). Niezmieniony kształt, objętość, 


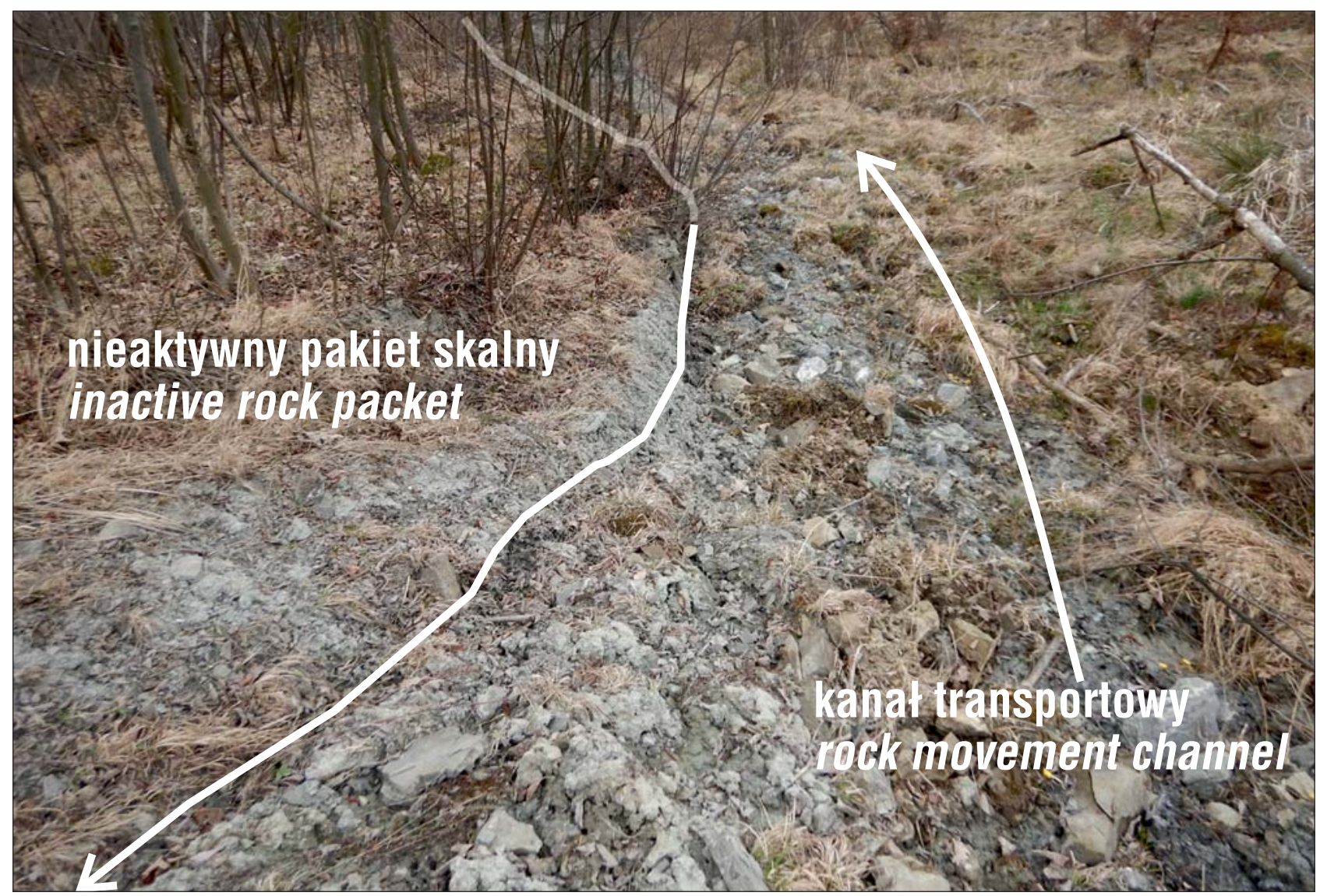

Ryc. 10. Obszar osuwiska, w którym zarejestrowano przemieszczenie horyzontalne wielkości 5 m (28.11.2017-24.03.2018 r.)

Fig. 10. Landslide area with 5-meter horizontal displacements (28.11.2017-24.03.2018)

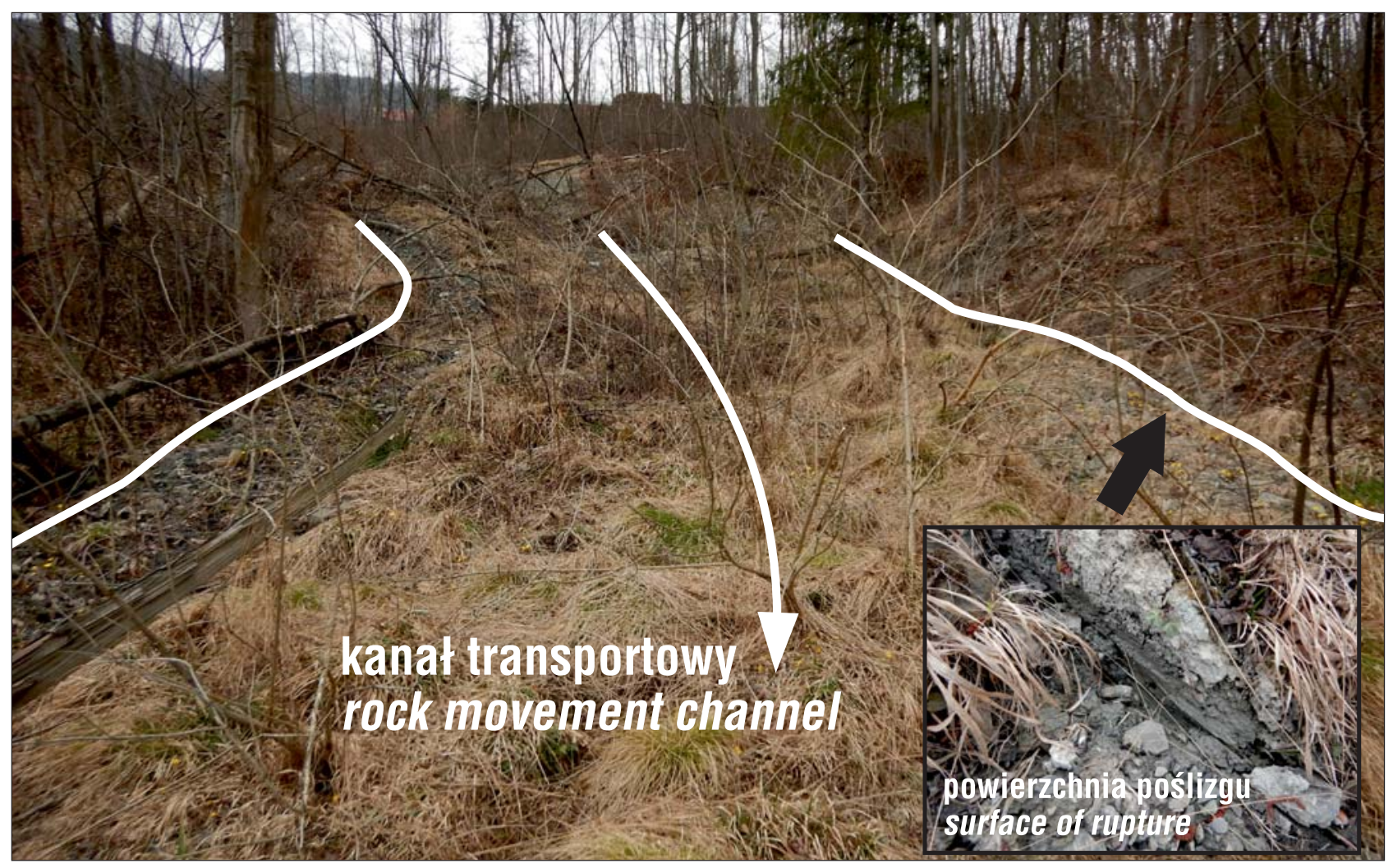

Ryc. 11. Kanał transportowy z rumoszem skalnym

Fig. 11. Rock movement channel 
a także wartości przesunięcia w poziomie tych stref świadczą o ruchu powolnym osuwiska, który nie powoduje większych deformacji osuwanych pakietów. Obszar jęzora osuwiskowego ze względu na obecność pokrywy roślinnej (drzewa, zarośla) w większości nie jest możliwy do przeanalizowania pod względem ruchów pionowych (ryc. 8C, 9C). Ruch w tej części osuwiska na wszystkich modelach różnicowych wykazuje tylko niewielki fragment czoła, który jest podcinany wodami Raby.

\section{PODSUMOWANIE}

Fotogrametria, jako zdalna metoda pomiarowa, dobrze sprawdza się w pomiarach terenów niebezpiecznych, np. osuwisk. Od niedawna do pozyskiwania zdjęć stosunkowo niewielkich obszarów jakimi są osuwiska używa się bezzałogowych statków latających, które mogą w autonomiczny sposób wykonywać wcześniej zaplanowane misje fotogrametryczne. Ze względu na ograniczenia sprzętowe UAV do pozyskiwania materiału zdjęciowego stosuje się lekkie kamery niemetryczne. Niedoskonałości optyczne takich sensorów są minimalizowane dużym pokryciem zdjęć oraz działaniem zaawansowanych algorytmów stosowanych w dzisiejszych aplikacjach fotogrametrycznych.

W przeprowadzonych badaniach do pomiaru powierzchni osuwiska wykorzystano quadrocopter DJI Phantom 4 Advance, za pomocą którego wykonanie zdjęć osuwiska z pikselem terenowym (GSD) ok. $2 \mathrm{~cm}$ było możliwe w trakcie pojedynczego nalotu. Materiał zdjęciowy z pokładu UAV został przetworzony na podstawie pomierzonej na powierzchni terenu osnowy fotogrametrycznej. W ten sposób uzyskano informację wysokiej rozdzielczości, co umożliwiło analizę przemieszczeń wertykalnych z dokładnością $10 \mathrm{~cm}$ oraz przemieszczeń horyzontalnych większych niż $15 \mathrm{~cm}$. Na duży margines błędu w przemieszczeniach w stosunku do rozdzielczości uzyskanych ortomozaik miał wpływ pomiar współrzędnych elementów charakterystycznych zastanych na powierzchni osuwiska (konary, głazy itd). Z jednej strony podejście takie ogranicza możliwości dokładnościowe ortomozaik oraz zawęża obszar pomiarowy tylko dla miejsc, w których obiekty charakterystyczne występują. Natomiast z drugiej - pozwala analizować ruch horyzontalny na dużej liczbie naturalnych obiektów (190 i 160 wektorów), bez konieczności instalacji znaków fotogrametrycznych na powierzchni osuwiska.

Ograniczeniem zastosowanej metody jest możliwość rejestrowania przemieszczeń tylko na odkrytym terenie. Próby klasyfikacji chmury punktów na obszarach pokrytych zwartą pokrywą roślinną okazały się nieskuteczne. Wyjątkiem jest drugi nalot zrealizowany 24.03.2018 r., na podstawie którego otrzymano wiarygodną powierzchnię terenu nawet w dolnej części jęzora osuwiskowego. W rozważaniu nad przemieszczeniami wywołanymi przez ruchy grawitacyjne pominięto analizę objętościową, z powodu zniekształceń modelu głównie na obszarze jęzora osuwiskowego. Analiza ta jest jednak możliwa do wykonania na wybranych obszarach osuwiska pozbawionych roślinności. Wyeliminowanie czynnika pokrywy roślinnej w budowie NMT jest możliwe przy zastosowaniu innych sensorów pomiarowych z pułapu drona, np. skanera laserowego (Ostrowski i in., 2017). Rozwiązanie to jest jednak kosztowne i przeznaczone do bardziej zaawansowanych technologicznie bezzałogowych platform latających.
Model bezzałogowego statku latającego zastosowany $\mathrm{w}$ badaniu ma też ograniczenia związane z panującymi warunkami atmosferycznymi. Zagrożeniem dla stabilności lotu są silne podmuchy wiatru, intensywne opady atmosferyczne czy ujemna temperatura. Na realizację nalotu fotogrametrycznego mają wpływ również aspekty prawne. Bezzałogowy statek latający jest użytkownikiem przestrzeni powietrznej prawie na takich samych warunkach jak statki załogowe. Misja lotnicza musi być realizowana zgodnie z aktualnie panującymi zasadami dla strefy powietrznej, w której ma odbywać się lot, co niekiedy uniemożliwia wykonanie nalotu w danym dniu.

Efekt przeprowadzonych badań można uznać za dobry, biorąc pod uwagę, że eksperyment został przeprowadzony na trudnym dla fotogrametrii obiekcie (pokrycie zwartą roślinnością). Cel badania został częściowo zrealizowany, uzyskano informację o wielkości przemieszczeń zachodzących na odsłoniętej powierzchni osuwiska, co pozwala stwierdzić, iż zaproponowana metoda stanowi skuteczne uzupełnienie monitoringu powierzchniowego prowadzonego punktowo na osuwiskach pozbawionych pokrywy roślinnej.

Badania zrealizowano $\mathrm{w}$ ramach działalności statutowej Państwowego Instytutu Geologicznego - Państwowego Instytutu Badawczego (nr 65.3606.1701.00.0).

\section{LITERATURA}

BEDNARCZYK Z. 2015 - Metody monitoringu osuwisk i wczesnego ostrzegania on-line na przykładzie badań geologiczno-inżynierskich w Beskidzie Niskim i Średnim. Prz. Geol., 63 (10/3): 1220-1229. BORKOWSKI A., PERSKI Z., WOJCIECHOWSKI T., JÓŹKÓW G., WÓJCIK A. 2011 - Landslides mapping in Roznow lake vicinity, Poland using airborne laser scanning data. Acta Geodynam. Geomaterial., 8/3 (163): 325-333.

BURTAN J. 1974 - Szczegółowa Mapa Geologiczna Polski w skali 1 : 50 000, ark. Mszana Dolna (1016). Państw. Inst. Geol., Warszawa.

CRUDEN D.M., VARNES D.J. 1996 - Landslide types and processes. Landslides, Investigation and Mitigation. Spec. Rep. 247, Transportation Research Board, Washington: 36-75.

GRANICZNY M., KAMIŃSKI M., PIĄTKOWSKA A., SURAŁA M. 2012 - Wykorzystanie lotniczego skaningu laserowego do inwentaryzacji i monitoringu osuwiska w rejonie Łaśnicy (gmina Lanckorona), Pogórze Wielickie, Karpaty zewnętrzne. Prz. Geol., 60 (2): 89-94.

GRANICZNY M., KOWALSKI Z., PLUTECKI W., WÓJCIK A. 2015 -

Zastosowanie bezzałogowych aparatów latających (BAL) w kartowaniu i monitoringu osuwisk w Karpatach. I Ogólnopolska Konferencja O!suwisko, 19-22 maja 2015, Wieliczka. Mat. konf., 22-24.

JUREWICZ E., KACZOROWSKI J., KLIMKIEWICZ D., KONON A., LUDWINIAK M., OZIMKOWSKI W., RUBINKIEWICZ J., SOBSTYL A., ŚMIGIELSKI M., TOMASZCZYK M. 2009 - Mapa osuwisk i terenów zagrożonych ruchami masowymi w skali 1 : 10 000, gm. Mszana Dolna, pow. limanowski, woj. małopolskie. http://mapa.osuwiska.pgi.gov.pl JÓŹKÓW G., WIECZOREK P., KARPINA M., WALICKA A., BORKOWSKI A. 2017 - Performance Evaluation of sUAS Equipped with Velodyne HDL-32E LiDAR Sensor. Int. Arch. Photogramm. Remote Sens. Spat. Inf. Sci., 42: 171-177.

KAMINSKI M. 2011 - Zastosowanie fotogrametrycznych modeli cyfrowych terenu i zdjęć lotniczych w badaniu dynamiki osuwiska Śliwnica (Pogórze Dynowskie). Biul. Państw. Inst. Geol., 446: 85-94.

KARWACKI K. 2016 - Zastosowanie modeli fotogrametrycznych $\mathrm{w}$ badaniu osuwiska w Lachowicach (Karpaty Zachodnie, Beskid Makowski). Biul. Państw. Inst. Geol., 466: 115-122.

KARWACKI K. 2018 - Modelowanie aktywności osuwisk z wykorzystaniem UAV. III Ogólnopolskie Symp. Geointerd. Met. Bad. Geosym, 11-13 kwietnia 2018: 40.

KOWALSKI A., WAJS J., KASZA D. 2018 - Monitoring of anthropogenic landslide activity with combined UAV and LiDAR-derived DEMs a case study of the Czerwony Wąwóz landslide (SW Poland, Western Sudetes). Acta Geodynam. Geomaterial., 15 (2): 117-129.

KRAMARSKA R., FRYDEL J., JEGLIŃSKI W. 2011 - Zastosowanie metody naziemnego skaningu laserowego do oceny geodynamiki wybrzeża 
na przykładzie klifu Jastrzębiej Góry. Biul. Państ. Inst. Geol., 446 $101-108$.

KURCZYŃSKI Z. 1997 - Zdjęcia lotnicze dla obszaru Polski realizowane $\mathrm{w}$ ramach programu modernizacji Krajowego Systemu Informacji o Terenie. Arch. Fotogrametrii, Kartografii i Teledetekcji, 6: 31-44. KURCZYŃSKI Z., STOJEK E., CISŁO-LESICKA U. 2014 - Zadania GUGiK realizowane w ramach projektu ISOK. [W:] Wężyk P. (red.), Podręcznik dla uczestników szkoleń z wykorzystania produktów LiDAR: 17-19.

LUCIEER A., DE JONG S. M., TURNER D. 2014 - Mapping landslide displacements using Structure from Motion (SfM) and image correlation of multi-temporal UAV photography. Prog. Phys. Geogr., (38): 97-116. NESCIERUK P., RĄCZKOWSKI W., WOJCIECHOWSKI T., WARMUZ B., KOWALSKI Z., MICHALSKI A. 2015 - Dokumentacja geologiczna z prac monitoringowych wykonanych na osuwisku w m. Kasinka Mała. Kraków. http://mapa.osuwiska.pgi.gov.pl

NESCIERUK P. 2015 - Instrumentalny monitoring osuwisk. I Ogólnopolska Konferencja O!suwisko, 19-22 maja 2015, Wieliczka. Mat. konf., 81-82.

NEUGIRG F., STARK M., KAISER A., VLACILOVA M., DELLA SETA, VERGARI F., SHMIDT J., BECHT M., HAAS F. 2016 - Erosion processes in calanchi in the Upper Orcia Valley, Southern Tuscany, Italy based on multitemporal high-resolution terrestrial LiDAR and UAV surveys. Geomorph., 269: 8-22.

NIETHAMMER U., JAMES M.R.., ROTHMUND S., TRAVELLETTI J., JOSWIG M. 2012 - UAV-based remote sensing of the Super_Sauze landslide: Evaluation and results. Geomorph., 128: 2-11.

OSTROWSKI W., GÓRSKI K., PILARSKA M., SALACH A. BAKUŁA K. 2017 - Porównanie koncepcji skanowania laserowego z bezzałogowych statków latających. Arch. Fotogrametrii, Kartografii i Teledetekcji, 29: 101-123.

PERSKI Z., BORKOWSKI A., WOJCIECHOWSKI T, WÓJCIK A 2011 - Application of persistent scatterers interferometry for landslides monitoring in the vicinity of Roznow Lake in Poland. Acta Geodyn. Geomater., 8/3 (163): 319-323.
PETRIE G. 2013 - Current developments in airborne laser scanners suitable for use on lightweight UAVs: Progress is being made! GeoInformatics, 16: 16-22.

PREUSS R., KURCZYŃSKI Z. 2002 - Koncepcja wytworzenia ortofotomapy dla potrzeb systemu identyfikacji działek rolnych - LPIS. Geodeta, 8 (87).

PRZYŁUCKA M., KLIMKOWSKA A. 2016 - Fotogrametria bliskiego zasiegu i skaning laserowy jako metody monitoringu zmian geodynamicznych na przykładzie skarpy w Płocku. Prz. Geol., 64 (7): 504-512. ROSSI G., TANTERI L., TOFANI V., VANNOCCI P., MORETTI S., CASAGLI N. 2018 - Multitemporal UAV surveys for landslide mapping and characterization. Landslide, 15: 1045-1052.

SALACH A., BAKUŁA K, PILARSKA M., OSTROWSKI W., GÓRSKI K., KURCZYŃSKI Z. 2018 - Accuracy Assessment of Point Clouds from LiDAR and Dense Image Matching Acquired Using the UAV Platform for DTM Creation. ISPRS Int. J. Geo-Inf., 7: 342.

STARKEL L. 1972 - Charakterystyka rzeźby polskich Karpat i jej znaczenie dla gospodarki ludzkiej. Probl. Zagosp. Ziem Górsk., 10: 75-150. TYSZKOWSKI S. 2008 - Badania rozwoju osuwisk w rejonie Świecia, na podstawie materiałów fotogrametrycznych. Land. Analys., 9: 385-389. WOJCIECHOWSKI T., BORKOWSKI A., PERSKI A., WÓJCIK A. 2012 - Dane lotniczego skaningu laserowego w badaniu osuwisk przykład osuwiska w Zbyszycach (Karpaty Zewnętrzne). Prz. Geol., 60 (2): 95-102.

WOJCIECHOWSKI T., PERSKI Z., WOJCIK A. 2008 - Wykorzystanie satelitarnej interferometrii radarowej do badań osuwisk w polskiej części Karpat. Prz. Geol., 56 (12): 1087-1091.

WÓJCIK A. 2011 - Karta rejestracyjna osuwiska nr 76932. http://mapa.osuwiska.pgi.gov.pl

WÓJCIK A., KOS J., JURCZAK S. 2017 - Rozpoznanie i próby zabezpieczenia osuwiska w Kurowie (Pogórze Rożnowskie, Karpaty Zewnętrzne). Prz. Geol., 65 (9): 576-585.

ZABUSKI L. 2013 - Ocena procesów osuwiskowych na podstawie wyników pomiarów inklinometrycznych. Prz. Geol., 61 (4): 248-256.

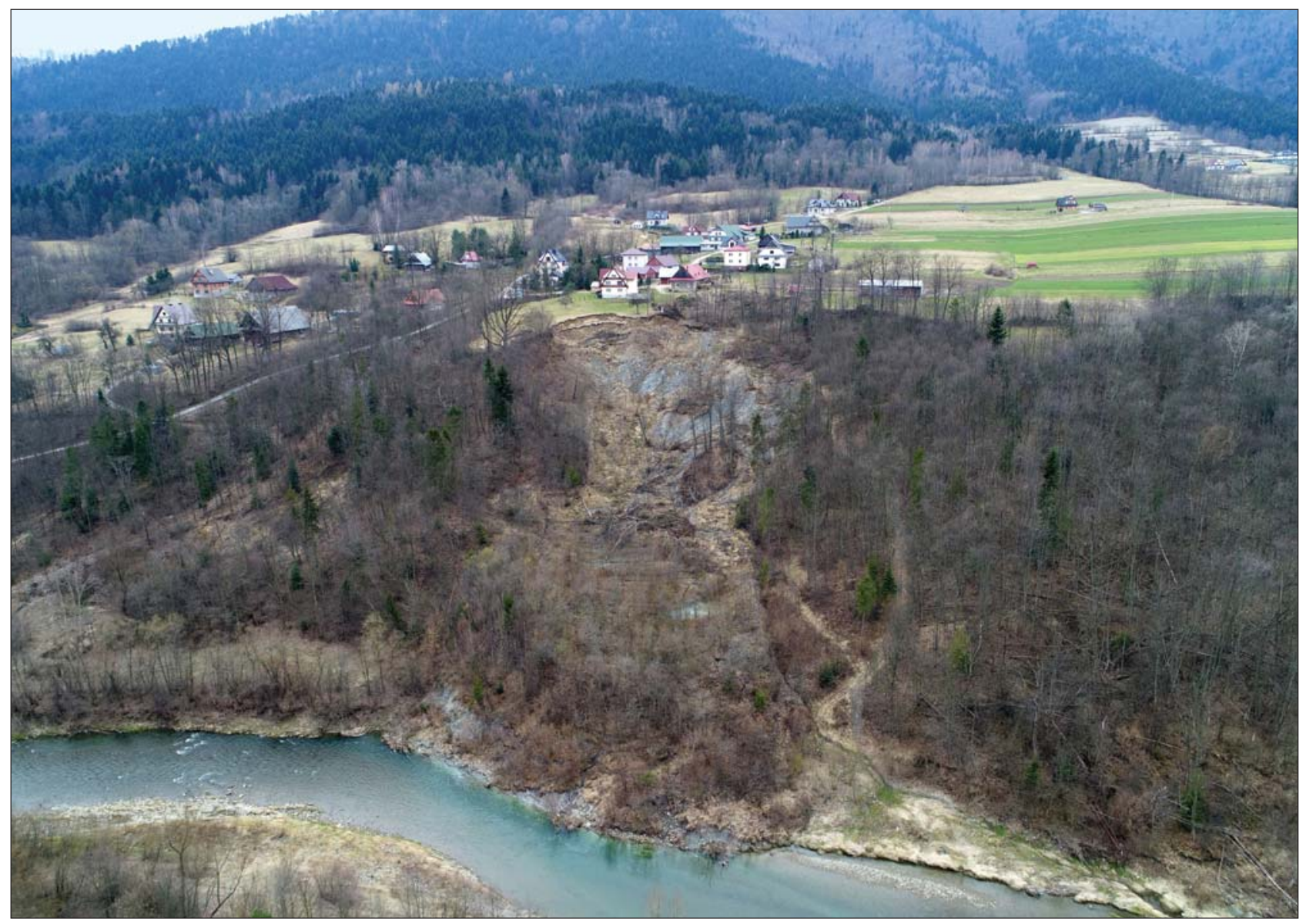

Widok z pułapu drona na aktywne osuwisko w Kasince Małej. Fot. K. Karwacki

Bird's-eye view UAV photography of an active landslide in Kasinka Mała village. Photo by K. Karwacki 